\title{
POP-UP RURAL SOCIALLY-INNOVATIVE HUBS - CASE STUDY FROM CROATIA
}

Sandra KANTAR, Križevci College of Agriculture, Milislava Demerca, 48260 Križevci, Croatia. skantar@ vguk.hr (corresponding author)

Kristina SVRŽNJAK, Križevci College of Agriculture, Milislava Demerca, 48260 Križevci, Croatia. ksvrznjak@vguk.hr

This paper presents formation of the first pop-up rural socially-innovative hubs in Croatia through the cooperation of higher education institutions, civil society organizations, students, alumni and local people in the specific rural communities of Međimurje and SplitDalmatia County. The main purpose of the hubs is to develop, test and validate an inclusive and participative program of service learning in the field of sustainable rural development. Pop-up rural hubs are mobile model of service learning that functions as an occasional event in the local community, to which all interested initiators are invited to join. From the sociological perspective, the most important aim of this project is to strenghten rural local communities through the launch of socio-innovative sustainable microentrepreneurial activities by using local resources. Through pop-up rural hubs, business ideas and plans are tested, and through additional mentoring and business plan, initiators were able to send the product or service on the market. Although the project is not over yet, the preliminary results show that pop-up rural socially-innovative hubs, within a period of one year project duration, stress the differencies and similarities between local communities in different parts of rural Croatia, enhance human capital and have a social impact on higher education institutions, civil society organizations, students, alumni and local people.

Keywords: pop-up rural hub, Croatia, innovation, service learning, rural community

\section{INTRODUCTION}

The rural area of the Republic of Croatia differs according to its natural-geographical, historical and cultural features, the landscape, the plant and animal world, tradition, habbits and economic development. ${ }^{1}$ Since about $92 \%$ of the land area of Croatia is occupied by rural space, in which about a fifth of the whole population lives, there is clearly a very large potential for the development. ${ }^{2}$ In the development of the rural areas in Croatia, Local Action Groups (LAGs) ${ }^{3}$ carry out the LEADER $^{4}$ program, create local partnerships by linking local stakeholders from the public, private and economic sectors and activate social capital to overcome the abovedescribed trends of socio-economic weaknesses. Social capital, according to Putnam, "refers to the characteristics of a social organization such as trust, norms and networks that can improve the efficiency of society by facilitating harmonized action" (2003:179). Social capital is (Kantar, 2016: 31), in fact, a bonding material, a "glue" that helps people to put their other financial, physical and human capital into the function of improving their common good and as such is a partial prerequisite development. Young and highly educated people is the most important bearers of social capital, and is very important to keep them in the rural area. An earlier study (Bótáné Horváth et al., 2015:20) examined the hypothesis, that creating an entrepreneurial team learning environment is a possible way to increase human and social capital in rural regions. Therefore, the project "POP-UP rural socio-innovative hubs" 5 has been launched with the aim of encouraging the development of rural local communities through the launch of socio-innovative activities and the local economy. The project through the cooperation of higher education institutions, civil society organizations, students and the local population in the specific rural communities of Međimurje and Split-Dalmatia County develops, tests and validates an inclusive and participative program of service learning in the field of rural development. The research objective of this paper is to present

\footnotetext{
${ }^{1}$ http://www.hmrr.hr/en/rural-development/what-is-rural-development

2 According to Svrznjak (et.al., 2014: 8) if the OECD definition is used, in connection with rural areas in Croatia, it can be concluded that $91.6 \%$ of the entire area of the Republic of Croatia is classified as rural, and only $8.4 \%$ is urban.

${ }^{3}$ LAG „The Hills and Valleys of Međimurje“ is the lead beneficary of the project „Pop-up rural hubs“. Other partners are Križevci College of Agriculture, VERN University from Zagreb, Faculty of Organization and Informatics from Varaždin, ACT Group (NGO) from Čakovec, students and alumni.

${ }^{4}$ LEADER (Liaison Entre Actions de Dévelopment de l'Economie Rurale) program is a European Union initiative to support rural development projects launched at local level to revitalize rural areas and create jobs.

${ }^{5}$ https://ruralhubs.net/o-projektu/
}

Copyright $\odot 2019$ The Authors. Published by Vytautas Magnus University. This is an open-access article distributed under the terms of the Creative Commons Attribution License (CC-BY 4.0), which permits unrestricted use, distribution, and reproduction in any medium, provided the original author and source are credited. 
and analyze the formation of the first pop-up rural socially-innovative hubs in Croatia ${ }^{6}$ as a driver of innovation and a constructive local partnership between different stakeholders from several sectors of activity.

\section{THEORETICAL BACKGROUND: RURAL HUBS IN EUROPEAN UNION}

The most current information about rural hubs can be found on the websites of particular rural hubs such as rural hubs from Italy ${ }^{7}$, Ireland ${ }^{8}$, Western Ukraine ${ }^{9}$, England ${ }^{10}$, France and other ${ }^{11}$. In general, the rural hub was founded by a group of education, training and rural development professionals as a response to the impact of the economic crisis on small rural villages and towns. ${ }^{12}$ Also, rural hub is considered as a rhizome of a network of researchers, activists, students, and managers interested in identifying new models of economic development. All those people are motivated to find new solutions to the needs (both social and market-related) of the new rural enterprises.$^{13}$ Analyzing available data, the authors conclude that there are several types of rural hubs ${ }^{14}$ in the EU:

1. RURAL ENTREPRISE HUB is based on rural economy activities with special focus on agriculture. According to Cowie, et al. (2013) rural entreprise hubs, ,... have an opportunity to be more than physical business spaces. They are capable of being key nodes in the flow of knowledge within the rural economy - both within the hub and between the hub and the wider economy." Rural hubs as places to meet for rural actors can have similar results as farmers' markets, where farmers notice the importance of cooperation (Lawson et al., 2008).

2. RURAL SOCIAL HUB is responding to demographic change and promote social inclusion issues in rural areas such as youths, women, migrants, refugees, Roma population, etc.

3. RURAL DIGITAL HUB offers physical spaces with fast, reliable internet access that provides a whole range of business and community support services in rural areas. The activities offered by digital hub depend on whether their target is businesses, the community or both ${ }^{15}$, and whether they provide space or also specific services to their target groups.

4. RURAL CREATIVE HUB is a place, either physical or virtual, which brings creative people together. It is a convenor, providing space and support for networking, business development and community engagement within the creative, cultural and tech sectors. ${ }^{16}$

5. ECO HUB is based on ideas that stimulate the use of local resources, lead to the preservation of tradition and nature, and potentially resolve social issues.

6. OTHER TYPES OF RURAL HUB provided by specific characteristics, requirements and requests of local people living in rural area.

The authors believe that rural hubs are one of the most important innovations that bring changes to EU rural areas and communities, including Croatia.

\section{METHODOLOGICAL BACKGROUND OF THE POP-UP RURAL HUB}

Good practise and analysis of some rural hubs were presented in previous chapter by reviewing relevant literature (web sources, academic articles etc.). In continuation, a rural hub from Croatia which is in a testing phase at the moment, will be described and analized within the framework of the ongoing project. Also, the authors used a small questionnaire about rural development and socio-entrepreneurial ideas on the sample of hub participants in two different counties and presented the results of the questionaires by description and analysis. The questionnaire for the students consisted of questions related to issues of improvments in local comunities, respodents' contribution in rural development projects, and projections of their socio-entrepreneurial (business) ideas. Entrepreneurs filled in the application form based on their real experience in bussines and future expectations. The process of organization and implementation of pop-up rural hubs is presented by schema.

\footnotetext{
${ }^{6}$ More about the project: Detelj, K., Kedmenec,I., Vuković, K., (2018) Service Learning as a Lever for Rural Social Entrepreneurship Development in Croatia, Economic and Social Development - 35th International Scientific Conference on Economic and Social Development - "Sustainability from an Economic and Social Perspective" - Book of Proceedings, Ribeiro, H., Naletina, D., da Silva, A. L. (ur.)., Lisabon, Portugal, 2018. str. 461468, https://www.researchgate.net/profile/Luiza_Kostecka-

Tomaszewska/publication/333093126_ECONOMIC_SECURITY_OF_CHINA_IN_21ST_CENTURY_SWOT_ANALYSIS/links/5cdb2dbc92851c4 eaba04b1b/ECONOMIC-SECURITY-OF-CHINA-IN-21ST-CENTURY-SWOT-ANALYSIS.pdf\#page $=474$

7 http://www.ruralhub.it/project/

8 https://theruralhub.ie/

9 http://www.creativeruralhub.org/

${ }_{10}$ http://www.hubrural.co.uk/

${ }_{11}$ https://enrd.ec.europa.eu/

12 https://theruralhub.ie/

13 http://www.ruralhub.it/project/

${ }_{14}$ Also, to distinguish rural hubs itselves, it is important to include other aspects such as: duration of events (long and short duration of events),

finance (private, public or both), stakeholders (external/domestic/both) and other

${ }^{15} \mathrm{https}$ ://enrd.ec.europa.eu/sites/enrd/files/tg_rural-businesses_case-study_rural-digital-hub_0.pdf

${ }^{16} \underline{\mathrm{http}: / / \text { creativehubs.net/tools/Creative-Hubs-Madrid-Toolkit_Final.pdf }}$
} 


\section{RESEARCH RESULTS AND DISCUSSION: ORGANIZATION AND IMPLEMENTATION PROCESS AT POP-UP RURAL HUB}

Rural hubs have not been represented so far and now they are considered to be innovative approaches to rural development that encourage the implementation of innovations as an indispensable part of the socio-entrepreneurial and socio-innovative undertaking (POP-UP MEET, 2018:2) ${ }^{17}$ In defining innovation, a general definition of innovation is understood as: "New strategies, concepts, ideas, processes, services, business models, tools, methodologies and policies or combinations of those that contribute to meeting the social needs. (Social Innovation Laboratory) ${ }^{18}$ Pop-up rural hubs are conceived as a model of service learning that functions as a periodical (pop-up) event/activity in the local community, within the framework of the activities of civil society organizations (primarily associations), to which all interested stakeholders and project developers are invited. Educated students and specialists would guide them to launch and/or develop socio-entreprenurial and socio-innovative undertaking. Service learning in community is a way for students to apply their theoretical knowledge in real life situation and contribute to the development of their community. Aside from giving young generations the opportunity to actively participate in solving social problems, it connects them with other relevant stakeholders in the community who can provide them with additional knowledge and skills. (scheme 1) Such intermittent, flexible hubs are not so organizational and resource-intensive, and in their rather open form they provide networking, an open, integrated and multidisciplinary approach, current methodology (such as lean approach), tools and technology. Currently, this model of flexible pop-up rural hubs is in the testing phase within the project and initiates and supports new and existing socio-innovative, micro-entrepreneurial ventures, as a potential future generators of socioeconomic development of local communities. If we apply the typology of rural hubs to a pop-up rural hub it is obvious that it is rural entreprise hub because it is directly connected with rural economy, but at the same time it is also a rural social hub because it wants to respond to demographic change by halting the departure of young people, especially educated people from rural areas. Who are the participants of the rural hub? There are several groups of hub participants: civil society organization and their employees, students from rural areas (Križevci College of Agriculture's ${ }^{19}$ students $=14$, VERN students=15, FOI students=9, teachers of higher education institutions, alumni, social innovators and entrepreneurs. Before the hubs were held, teachers mentored students and members of civil societies in order to test and evaluate entrepreneurial ideas.

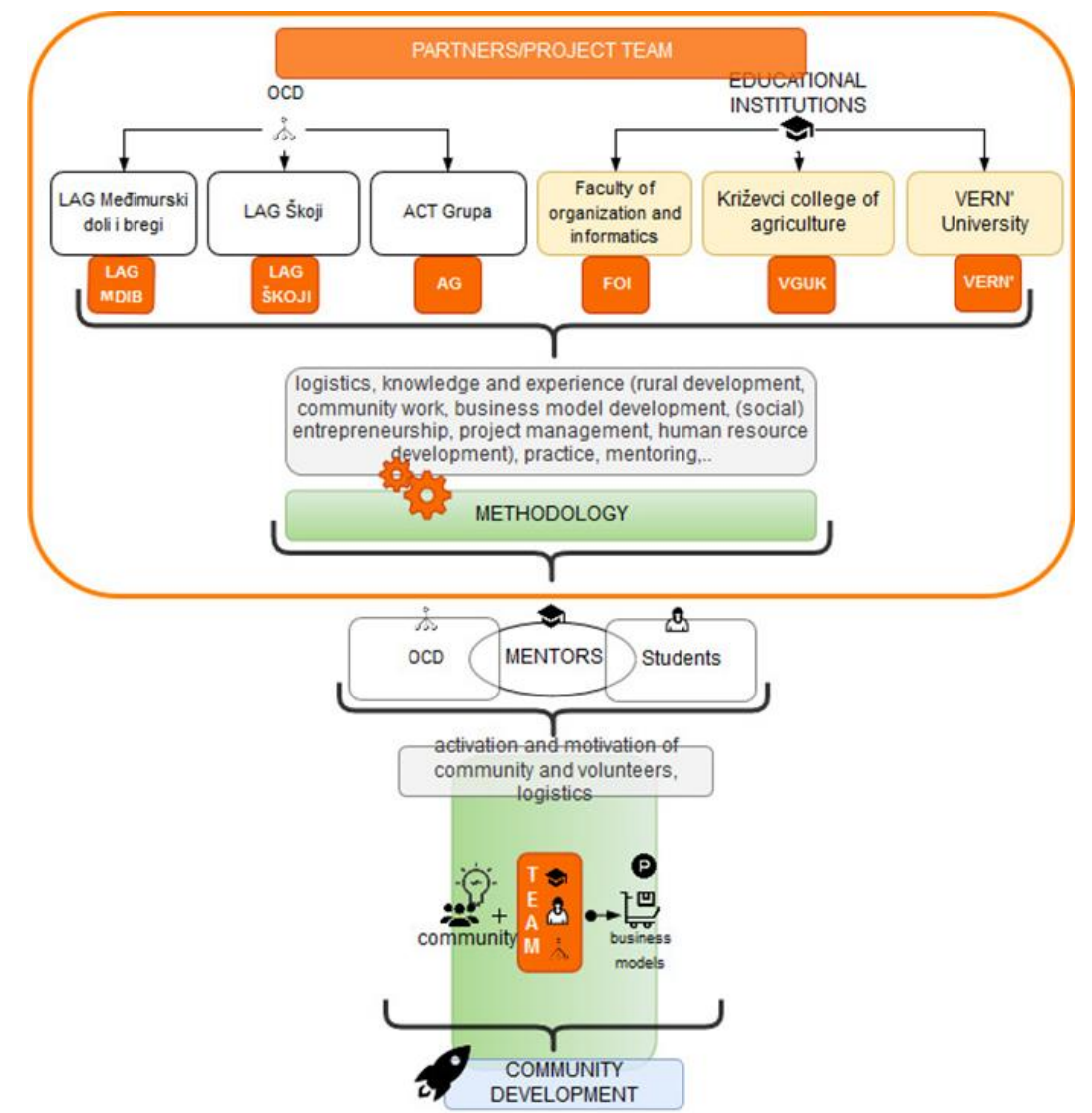

Source: POP-UP MEET - Methodology and models for local communities and local economy development through mobile (POP-UP) socio-innovative rural hubs (2018:3)

Figure 1. Organization of POP-UP RURAL HUB

\footnotetext{
${ }^{17}$ Group of authors: POP-UP MEET - Methodology and models for local communities and local economy development through mobile (POP-UP) socio-innovative rural hubs.

${ }^{18}$ http://hkkkki.eu/index.php/project/sil/

${ }^{19}$ Križevci College of Agriculture in further text is KCA
} 
Pop-up rural hubs were held in Međimurje County and in the city of Vis ${ }^{20}$ at Split - Dalmatia County. ${ }^{21} \mathrm{By}$ submitting their ideas, initiatives and entrepreneurial ventures, through three days of rural pop-up hubs, applicants were provided with knowledge, experience, and support in development of their ideas by representatives of local associations, students and experts involved in the project. Eligible applicants were family farm owners, craftsmen, entrepreneurs, unemployed, representatives of associations, students and all the other members of the local community who would like to transform their entrepreneurial idea into reality and contribute to the development of the local community. All participants responded to a short questionnaire ${ }^{22}$ to gain an insight into their fundamental interests in rural development and socio-entrepreneurial ideas that students and entrepreneurs would like to accomplish within the pop-up rural hub. Students from $\mathrm{KCA}^{23}$ are mostly educated in the field of rural development, and VERN students in social entrepreneurship, social innovations and entrepreneurship, but KCA students are proud to point out practical (working) experience in private sector, especially at family farms. KCA students recommended some aspects of rural development at Međimurje County and Vern students did the same for Island Vis. In particular, for rural development in Međimurje County, according to students recommendations, it is most important to subsidize family farms and in this regard establish environmental protection measures in agriculture and forestry. It is also important to encourage development of rural tourism (wine tourism and agrotourism) and preserve the cultural heritage and customs of the Međimurje region. In order to develop these activities more successfully, it is necessary to restore, renew and develop the village and traditional rural crafts. A major problem for the rural population is the inadequate management of agricultural land that needs to be improved by quality land policy measures at the national level in order to develop agriculture as the main economic branch more successfully. If all the necessary activities for a stronger rural development are implemented, it will be easier to encourage small, medium and female entrepreneurship and strenghten civil society organizations (associations, NGOs etc.) and thus contribute to the overall integrated and sustainable development of the rural area. What is needed for rural development of the island of Vis? The list of priorities is somewhat shorter (due to the fact that in Vis tourism is the main economic branch) and includes: the development of small and medium entrepreneurship, the promotion of rural tourism (wine tourism and agrotourism), preservation of cultural heritage and customs, and the restoration and development of villages. In developing these activities, students can support local innitiatives because most of them have experience in implementing various projects. For example, KCA students believe that in the rural hub, they can best assist in developing business ideas, creating a marketing idea and promoting it, while VERN students with the knowledge they own can best assist in market and competition research, and planning the business activities within the required resources. For the rural development projects, students consider that skills such as teamwork, communication and presentation skills, flexibility, quick learning and observation, quick decision-making and time management are particularly important. KCA students have the following entrepreneural ideas ${ }^{24}$ : playgrounds for children in a rural-tourist destinations, establishing women entrepreneurs in rural areas, local markets (short chains supply) for high-quality domestic agricultural products, presentation of Međimurje through agritourism, agricultural store: purchase and sale of agricultural products, etc. Unlike entrepreneurial ideas of students, entrepreneurs create (10) ideas that are a logical continuation or more detailed elaboration of their entrepreneurial activities at the moment at hub in Mala Subotica ${ }^{25}$ : cattle breeding, production of soaps, scented salts, pralines and bath bombs as souvenirs with the possibility of use, manufacture of bags made of natural material (jute), decorative boxes, paper towels, paper toys, jewelery, ecological production of berry tea, ecological production of husk oil+nuts, production of domestic vegetables: tomatoes, salads, peppers and cucumbers with door delivery, hunting as a Sports Tourist Service, sale and purchase of used cars, book about vegetable gardening, the production of honey and the organization of a themed room about bees, beekeeping and honey production. Business idea at second hub (in Štrigova) was similar: development of culture and horticulture in a rural-tourist-agricultural facility in the rural area, photography, pottery workshops, establishing women's rural association, beekeeping services and products, rural holiday house, gourmet and gastronomic offer of domestic specialties from Međimurje, etc. Unfortunately, on island Vis only Children's and Youth Association participated on hub and applied only one entrepreneural idea with focus on expansion of existing programs and introduce new ones.

\section{DISCUSSION AND CONCLUSION}

More hubs are planned within the project in the future, but at the moment testing business ideas and plans through the rural hubs is much more successful in Međimurje county because of many ideas wich are linked to the already existing activities and the upgrading of new ones. People living in the local community in Medimurje have entrepreneurial mentality and ethics, better responds to community events and collaborate with each other successfully, so it proves that

\footnotetext{
${ }^{20}$ Pop-up rural hub on the island of Vis was held only at October 2019. because participants were involved in tourism

${ }^{21}$ Application form Pop-up Rural Hubs: https://lag-medjimurskidoliibregi.hr/en/ongoing-projects/\#ongoing4

22 The Questionnaire (Student Application) was created within the framework of the POP -UP RURAL HUBS project:https://docs.google.com/forms/d/e/1FAIpQLSfA1zk9F9wn75bRdmuVA7QTu7c6uyguLoNg1e_NfIVjz10Oww/viewform
}

${ }^{23}$ Students and alumni of KCA undertake undergraduate professional studies in the field of "Management in Agriculture" on Bsc level and „Management in Agricultural level on Msc level, and students from VERN attend Undergraduate Professional -"Entrepreneurship Economics" as well as FOI students.

${ }^{24}$ VERN's students and FOI's students did not plead their business idea at the questionnaire.

${ }^{25}$ Mala Subotica was the first hub held in Međimurje County 
they have a larger social capital and are prone to innovations. Unlike Međimurje, the rural hub on the island of Vis has less participant responses and hence a far smaller number of entrepreneurial ideas. It can be assumed that island isolation and seasonality in tourism are influenced on low social capital in that rural community. From a sociological perspective the most important aim of rural hubs is to strenghten rural local communities through the launch of socio-innovative sustainable micro-entrepreneurial activities by using local resources, so rural hubs, as a flexible model, can be one of a sustainable model by which we create a better life in the rural community.

\section{REFERNCES}

1. Application form for participation in education under the POP-UP Rural Hubs project. Available at https://docs.google.com/forms/d/e/1FAIpQLSfA1zk9F9wn75bRdmuVA7QTu7c6uyguLoNg1e_NfIVjzl0Oww/vie wform (accessed on (02/04/2019)

2. Bótáné H., N., Katonáné Kovács J., Szőke Sz. 2015. Building an entrepreneurial environment in rural regions: a possible way to develop human and social capital. Studies in Agricultural Economics, Vol. 117, pp. 20-26. https://doi.org/10.7896/j.1428

3. Ceative Rural Hub. 2019. Available at http://www.creativeruralhub.org/ (accessed on 13/05/2019)

4. Croatian Innovation Laboratory.2015. Available at http://hkkkki.eu/index.php/project/sil/ (accessed on 02/04/2019)

5. Croatian Rural Development Network. 2019. What is Rural Development? Available at http://www.hmrr.hr/en/ruraldevelopment/what-is-rural-development (accessed on 09/05/2019)

6. Cowie P., Thompson N., Rowe F. 2013. Honey Pots and Hives: Maximising the potential of rural enterprise hubs (unpublished research report). Department for Environment, Food and Eural Affairs, Newcastle University.

7. European Creative Hubs Network. How to Set Up a Creative Hub. 2019. Available at http://creativehubs.net/tools/Creative-Hubs-Madrid-Toolkit_Final.pdf (accessed on 17/06/2019)

8. European Network for Rural Development. 2019. Revitalising rural areas through digitisation : The experience of three rural digital hubs. Available at https://enrd.ec.europa.eu/sites/enrd/files/tg rural-businesses_case-study_ruraldigital-hub_0.pdf (accessed on 17/04/2019)

9. Group of authors 2018: POP-UP MEET: Methodology and models for local communities and local economy development through mobile (POP-UP) socio-innovative rural hubs (unpublished research report). ACT Group. Čakovec.

10. Hub Rural. 2019. Available at http://www.hubrural.co.uk/ (accessed on 14/05/2019)

11. Kantar, S. 2016. Development of sustainable rural tourism: potentials of Koprivničko-križevačka county. Doctoral thesis. Department for Sociology, Philosophical Faculty, Zagreb.

12. LAG „The Hills and Valleys of Međimurje“. 2019. Ongoing Projects. Available at https://lagmedjimurskidoliibregi.hr/en/ongoing-projects/\#ongoing4 (accessed on 10/05/2019)

13. Lawson R., Guthrie J., Cameron A., Fischer W. C. 2008. Creating value through cooperation: An investigation of farmers' markets in New Zealand. British Food Journal, Vol. 110(1), pp. 11-25. https://doi.org/10.1108/00070700810844768

14. Putnam R. 2003. Making Democracy Work: Civic Traditions in Modern Italy.Zagreb:Faculty of Political Science.

15. Rural Hub. 2019. Project. Available at http://www.ruralhub.it/project/ (accessed on 11/05/2019)

16. Social Innovation Laboratory.2013. Available at http://hkkkki.eu/index.php/project/sil/ (accessed at 17/06/2019)

17. Svržnjak K., Kantar S., Jerčinović S., Kamenjak D. 2014. Rural Tourism - An Introduction to Destination Management, Križevci College of Agriculture, Križevci.

18. The Rural Hub. 2019. Available at https://theruralhub.ie/ accessed on 12/05/2019) 